\title{
О.В. Обернихина
}

\section{ТЕОРЕТИКО-ПРАВОВЫЕ ОСНОВЫ ОРГАНИЗАЦИИ КОНТРОЛЯ ЗА ЛИЦАМИ, ОТБЫВАЮЩИМИ НАКАЗАНИЯ БЕЗ ИЗОЛЯЦИИ ОТ ОБЩЕСТВА}

\begin{abstract}
Рассматриваются наиболее актуальные проблемы организации контроля за лицами, отбывающими различные виды наказания, не связанные с лишением свободы. Исследуются причины и условия совершения повторной преступности указанной категорией осужденных, стоящих на учете в уголовно-исполнительных инспекциях. Приводятся примеры положительного зарубежного опыта организации контроля за подучетными лицами посредством ряда технических средств.
\end{abstract}

Ключевые слова: уголовно-исполнительная инспекция, контроль, повторная преступность, рецидивная преступность.

Широкое распространение в уголовной и уголовноисполнительной политике Российской Федерации приобрели направления на гуманизацию всей уголовной юстиции, а также дифференциацию мер уголовной ответственности и наказания. Представляется, что преобразования такого вида не влекут за собой негативные последствия, в частности, значительно увеличилось количество латентных преступлений, как естественных, так и искусственных. Если латентность как социальное явление отследить сложно, то информация о повторной преступности периодически фигурирует в различных официальных источниках. Особые опасения вызывают увеличивающиеся показатели организованной преступности.

Ели показатели статистической отчетности о преступности в Российской Федерации волнуют в большей степени представителей законодательной и исполнительной власти, то общество волнуется не столько о количественных показателях преступности, сколько о ее качественном аспекте. Такое положение вполне оправдано, поскольку рост количества преступлений упомянутого характера снижает уровень безопасности в обществе. Это проявляется не только в совершении новых противоправных деяний лицами, ранее совершившими преступления, но и в аккумулировании опасных категорий в системе исполнения наказания, к такой категории следует отнести лиц, отбывающих различные виды наказания без изоляции от общества.

Таким образом, на плечи Уголовно-исполнительной инспекции ФСИН РФ (далее - УИИ), ложиться обязанность контролировать исполнение наказаний наиболее рецидивоопасного контингента. Повторные преступления и правонарушения со стороны лиц к наказаниям без изоляции от общества, являются показателем, который негативно характеризует не только деятельность органа, осуществляющего исполнение наказания, но и, предположительно, сам правовой институт исполнения наказаний без изоляцией от общества.

Разработка и принятие организационных и практических мер, направленных на повышение эффективности работы по предупреждению совершения преступлений и других правонарушений осужденными, осуществляются на основе анализа деятельности ОВД и УИИ (Приказ Минюста России № 190, МВД России № 912 от 04.10.2017 г. (ред. от 20.01.2017 г.) «Об утверждении Регламента взаимодействия ФСИН России и МВД России по предупреждению совершения лицами, состоящими на учете в УИИ, преступлений и правонарушений») [1, с. 3-6].

В структуре уголовных наказаний значительное место занимают наказания, не связанные с лишением свободы. Так, к реальному лишению свободы в 2012 г. было осуждено 28\%, в 2013 г. - 28,7\%, в 2014 г. $29,4 \%$, в 2015 г. - $33 \%$, в 2016 г. - 28,5 \% подсудимых, остальные, в среднем это $60 \%$, приговариваются к наказаниям, не связанным с изоляцией от общества [2, с. 164]. Причем в последние пять лет значительно увеличилось количество повторных преступлений, совершенных лицами, условно осужденными.

Представляется, что для того чтобы повысить эффективность деятельности УИИ, необходимо дифференцировать их по видам наказания, общественной опасности и распространенности составов преступлений.

С криминологической точки зрения рецидивная преступность является результатом криминогенного влияния особенностей личности человека, например таких, как агрессивность, чувство безнаказанности, различного рода деградации в сочетании с негативным воздействием социальных факторов. Так, при исполнении альтернативных лишению свободы наказаний повторная преступность как общественное явление представлена комплексом криминогенных критериев, влияние которых, зачастую, определяет характер и виды преступности уже в условиях исполнения упомянутых видов наказания. В качестве критериев повторной, рецидивной преступности в УИИ целесообразно выделить несколько основных: отсутствие эффективных мер и способов организации контроля за подучетными лицами, не способность последних к ресоциализации, а также отсутствие у инспекторов УИИ возможности осуществлять профилактические мероприятия.

Характер динамики и негативный прогноз рецидивной преступности значительно усложняют организацию работы сотрудников УИИ при снижении численности лиц, состоящих на их учете. Об этом свидетельствуют показатели роста количества профилактических мер, предпринимаемых сотрудниками УИИ, в частности: продление испытательного срока в отношении условно осужденных; возложение дополнительных обязательств на условно осужденных; различные меры, связанные с привлечением к труду осужденных. 
Широкое распространение в последние несколько лет получил передовой международный опыт по организации исполнения наказаний и мер, не связанных с лишением свободы. Зачастую он носит экспериментальный характер, в ходе чего инспекторами УИИ апробируются принципиально новые технические средства контроля за осужденными, что позволяет исполнять наказание, исключая отрицательную деформацию или даже деградацию личности правонарушителя. Так, например, в рамках проекта Европейской комиссии «Альтернативы лишению свободы в Российской Федерации», осуществляемого на базе УФСИН России по Воронежской области в 2014 г., проводилось исследование по определению эффективности применения системы электронного мониторинга и GPSслежения. В качестве преимущества электронной системы мониторинга можно отметить улучшение условий труда сотрудников УИИ за счет непрерывного, круглосуточного надзора посредством бесконтактного наблюдения.

Особым интересом у практических работников УИИ пользуется проект по введению электронной регистрации осужденных к наказаниям, не связанным с лишением свободы, через видеотерминалы, поскольку осуществление контрольных мероприятий подобным образом может в разы сократить занятость каждого из инспекторов. Предварительный анализ показал, что внедрение современных технических средств контроля (видеотерминалы) за условно осужденными позволяет повысить эффективность работы по профилактике рецидивной преступности. Так, в ходе эксперимента было установлено, что ни один из 85 осужденных, которые регистрировались через видеотерминалы в УИИ, не совершил ни одного правонарушения или повторного преступления. Инспектора УИИ получили возможность чаще общаться с подучетными осужденными, так как они проходят электронную регистрацию еженедельно. Преимуществом является и то, что аппаратура для видеорегистрации установлена в администрациях населенных пунктов, что позволяет контактировать осужденным с главами администраций, попросить помощи, например, в трудоустройстве, решить жилищные проблемы, если необходимо. Представленный эксперимент позволил включить органы местного самоуправления в процесс профилактики рецидивной преступности.

При решении задач, поставленных государством перед УИИ о выполнении последними их основных функ- ций, встал вопрос не только о применении технических средств надзора, но и о использовании автотранспортных средств. В этом направлении инспекции были обеспечены автомобилями, что, в свою очередь, оказывает значительную помощь сотрудникам инспекций при выполнении служебных обязанностей [2, с. 140-144].

Несмотря на возможность реформирования системы организации исполнения наказаний, альтернативных лишению свободы, повышение эффективности деятельности УИИ, в частности по осуществлению контрольных мероприятий, в настоящее время институт исполнения наказаний, не связанных с изоляцией от общества, переживает системный кризис, который вызван в первую очередь организационной и ресурсной нестабильностью.

Нельзя сказать, что государство игнорирует наличие указанных проблем. Так, например, по итогам оперативного совещания Совета Безопасности Российской Федерации «О мерах по предупреждению рецидивной преступности в Российской Федерации» Правительству Российской Федерации поручено с участием органов государственной власти субъектов Российской Федерации разработать комплекс нормативно-правовых и организационных мер по стимулированию работодателей к организации рабочих мест для осужденных к исправительным работам. Некоторые субъекты Российской Федерации уже ведут работу по привлечению сторонних организаций к трудоустройству осужденных. Например, в Кемеровской области вступил в силу Закон Кемеровской области № 114-О3 от 01.01.2015 г. «О налоговой льготе в 2015-2017 годах отдельным категориям налогоплательщиков, использующих труд лиц, отбывающих наказание в виде лишения свободы» [3], где предусмотрены налоговые льготы для организаций, предоставляющих рабочие места и использующие труд лиц, стоящих на учете в УИИ. Причем работодатель невольно включается в процесс исполнения наказания, в частности исправительных работ, поскольку вынужден контролировать присутствие осужденного на рабочем месте, давать характеристики и оценивать качество работы подучетного лица УИИ.

В целом, объем и сложность стоящих перед уголовно-исполнительной системой задач, в том числе по ее реформированию, требуют улучшения качества подготовки сотрудников, привлечения на службу квалифицированных специалистов, обладающих высоким уровнем знаний и навыков правовой культуры и морально-нравственных качеств [4].

\section{ЛИТЕРАТУРА}

1. Дегтярева О.Л. Общегосударственные особенности роста и снижения уровня повторной преступности среди лиц, осужденных к наказаниям и мерам уголовно-правового характера, не связанным с изоляцией осужденных от общества, в общей структуре преступлений, совершаемых на территории страны // Уголовно-исполнительная система: право, экономика, управление. 2015. № 1. С. 3-6.

2. Преступность и правонарушения (2012-2016) : статистический сб. М., 2017. С. 180.

3. Закон Кемеровской области от 24.11.2014 г. № 114-ОЗ (ред. от 06.10.2017) «О налоговой льготе в 2015-2017 годах отдельным категориям налогоплательщиков, использующих труд лиц, отбывающих наказание в виде лишения свободы» (принят Советом народных депутатов Кемеровской области 19.11.2014) // СПС КонсультантПлюс.

4. Постановление Правительства РФ от 15.04.2014 г. № 312 «Об утверждении государственной программы Российской Федерации “Юстиция”» // СПС КонсультантПлюс. 


\section{TEORETICAL AND LEGAL BASES OF THE ORGANISATION OF CONTROL OVER PEOPLE SENTENCED TO PUN- ISHMENT WITHOUT ISOLATION FROM SOCIETY}

Ugolovnaya yustitsiya - Russian Journal of Criminal Law, 2018, no. 11, pp. 167-169. DOI 10.17223/23088451/11/33

Olesya V. Obernikhina, Kuzbass Institute of the Federal Penitentiary Service of Russia (Novokuznetsk, Russia). E-mail: Olesia.obernihina@yandex.ru.

Keywords: penitentiary inspection, control, repeated crime, recidivism.

The desire of the legislator to bring modern criminal and penal enforcement legislation in line with international standards has led to the fact that a number of criminally punishable offenses became administrative; sanctions for a number of crimes included compulsory labour as an alternative punishment to deprivation of liberty, and a relatively new penal measures of deferred sentence appeared. All this led to a significant reduction in the number of persons sentenced to imprisonment and increased the number of those are sentenced to various penalties without isolation from society. The level of public security seems to have increased significantly, but one should not rush to conclusions, since the public danger of those who committed crimes previously punished with deprivation of liberty (substituted with alternatives penalties now) cannot simply cease to exist from the moment of release or transfer from the correctional institution to the penitentiary inspection. This is confirmed by the rates of recidivism, as well as statistics on the number of repeated crimes, among which a special place is occupied by those that were committed by persons serving sentences alternative to deprivation of liberty. Presumably, the ineffectiveness of the execution of punishments and other penal measures alternative to deprivation of liberty can be explained by the fact that the penitentiary inspectors are unable to implement the measures required by the penal enforcement legislation to achieve the purposes of punishment due to practical problems, which will be discussed further. It all often comes to one thing - the organization of control of the accountants. This turns out to be insufficient to correct the convict, to help them become a law-abiding citizen, to create social conditions which can prevent them from committing new criminal acts. Thus, the assessment of the effectiveness of the penitentiary inspectorates is incapable of giving objective results, especially since the assessment methods are seriously outdated, the number of these units of the penal enforcement system is insufficient to organise the execution of penalties against such a large number of convicts who stand on account in the penal institute.

\section{REFERENCES}

1. Degtyareva, O.L. (2015) Nation-wide peculiarities of increase and reduction of the level of repeated crime among persons convicted to punishments and measures of criminal-law character not connected with isolation of the convicts in a general structure of crimes committed on the territory of the country. Ugolovno-ispolnitel'naya sistema: pravo, ekonomika, upravlenie - Criminal-Executory System: Law, Economy, Management. 1. pp. 3-6. (In Russian).

2. Ministry of Internal Affairs of the Russian Federation. (2017) Prestupnost' i pravonarusheniya (2012-2016). Statisticheskiy sbornik [Crime and offenses (2012-2016). Statistics]. Moscow: Ministry of Internal Affairs of the Russian Federation.

3. Kemerovo Region. (2014) Law No. 114-OZ of Kemerovo region of November 24, 2014, (as amended on October 6, 2017) "On the tax privilege in 2015-2017 for certain categories of taxpayers using the labour of persons serving sentences in the form of deprivation of liberty" (adopted by the Council of People's Deputies Kemerovo region November 19, 2014). [Online] Available from: http://www.consultant.ru/regbase/cgi/online.cgi?req=doc;base=RLAW284;n=83766\#04154195192370038. (In Russian).

4. The Government of the Russian Federation. (2014) Resolution No. 312 of the Government of the Russian Federation of April 15, 2014, "On the approval of the "Justice" State Program of the Russian Federation. [Online] Available from: http://www.consultant.ru/document/cons_doc_LAW_162180/. (In Russian). 